\title{
OPTIMAL REACTIVE POWER DISPATCH UNTUK MEMINIMISASI RUGI-RUGI DAYA AKTIF PADA SISTEM LAMPUNG MENGGUNAKAN METODE GREY-WOLF OPTIMIZER (GWO)
}

\author{
Osea Zebua $^{1^{*}}$, I Made Ginarsa ${ }^{2}$ \\ ${ }^{1}$ Staf Pengajar Jurusan Teknik Elektro Universitas Lampung \\ ${ }^{2}$ Staf Pengajar Jurusan Teknik Elektro Universitas Mataram \\ "Corresponding author, e-mail : oseaz2009@ gmail.com
}

\begin{abstract}
Abstrak - Optimal reactive power dispatch bertujuan untuk memperoleh operasi yang aman dan ekonomis dari sistem tenaga listrik dengan mengatur alokasi daya reaktif pada sistem tenaga listrik, antara lain dengan mengatur tegangan generator, kapasitas kapasitor paralel dan posisi tap transformator. Optimal reactive power dispatch adalah masalah optimisasi kombinasi yang kompleks dan lebih mudah diselesaikan dengan menggunakan metode-metode berbasis kecerdasan buatan. Makalah ini menyajikan penyelesaian masalah optimal reactive power dispatch untuk meminimisasi rugi-rugi daya aktif menggunakan metode grey-wolf optimizer dengan sistem kelistrikan Lampung sebagai studi kasus. Perangkat lunak Matpower 5.1 digunakan untuk menghitung aliran daya dan rugi-rugi daya aktif. Simulasi dilakukan dengan mengatur tegangan pada setiap bus atau gardu induk yang terhubung dengan generator dengan batas 0,95 pu sampai $1,05 \mathrm{pu}$, mengatur posisi tap transformator pada gardu induk Gumawang dan Seputih Banyak dengan batas 0,95 pu sampai 1,025 pu dan mengatur nilai kapasitas kapasitor pada gardu induk Natar, Sutami dan Kalianda dengan batas 0 sampai 25 MVAR. Hasil simulasi menunjukkan bahwa metode grey-wolf optimizer dapat mengurangi rugi-rugi daya aktif dari 18,97 MW menjadi 18,2377MW.
\end{abstract}

Kata Kunci : optimal reactive power dispatch, grey-wolf optimizer, minimisasi rugi-rugi.

\begin{abstract}
Optimal reactive power dispatch has a purpose to achieve secure and economic operation of power system by regulating reactive power allocation in electric power system, such as regulating generators voltage, capacity of shunt capacitors and tap position of transformers. The optimal reactive power dispatch is complex combinatorial optimization problem and more easily solved by using artificial intelligence-based methods. This paper presents the solving of optimal reactive power dispatch problem to minimize active power loss using grey-wolf optimizer method with Lampung electrical power system as a case study. Matpower 5.1 software is used to calculate power flow and active power losses. The simulation is performed by regulating the voltage on each bus or substation connected to the generator with the limit of 0.95 pu to $1.05 \mathrm{pu}$, adjusting tap position of transformer on Gumawang and Seputih Banyak substations with a limit of $0.95 \mathrm{pu}$ to $1,025 \mathrm{pu}$ and regulating the capacity of shunt capacitors in Natar, Sutami and Kalianda substations with a limit of 0 to 25 MVAR. The simulation results show that the gre-wolf optimizer method can reduce the total active power losses from $18.97 \mathrm{MW}$ to $18.2377 \mathrm{MW}$.
\end{abstract}

Keywords : optimal reactive power dispatch, grey-wolf optimizer, loss minimization

Copyright $@ 2017$ JNTE. All rights reserved

\section{PENDAhULUAN}

Optimal reactive power dispatch atau penyaluran daya reaktif yang optimal bertujuan untuk operasi yang aman dan ekonomis dari sistem tenaga listrik. Masalah penyaluran daya reaktif yang optimal adalah masalah untuk mengalokasikan pembangkitan daya reaktif untuk meminimisasi rugi-rugi daya aktif transmisi atau meminimisasi deviasi tegangan dengan memenuhi fungsi-fungsi batasan, antara lain, batas atas dan batas bawah dari tegangan operasi dari generator, dan sumber daya reaktif pada sistem tenaga listrik seperti generator, kapasitor dan tap transformator.

Masalah penyaluran daya reaktif adalah masalah optimisasi kombinasi yang sangat kompleks yang mengikutsertakan fungsi yang nonlinier dengan fungsi batasan yang nonlinier dengan variabel yang diskrit dan kontinyu.

Berbagai teknik dan metode berbasis pemrograman matematis [1,2] telah digunakan untuk menyelesaikan permasalahan optimal reactive power dispatch, dan metode berbasis 
matematis membutuhkan waktu yang lama untuk menemukan penyelesaian. Metode penyelesaian berbasis kecerdasan buatan (artificial intelligence) lebih cepat untuk mengatasi kesulitan yang dihadapi oleh penggunaan metode berbasis pemrograman matematis [3-5].

Makalah ini menyajikan penyelesaian optimal reactive power dispatch untuk meminimisai rugi-rugi daya aktif sistem kelistrikan Lampung menggunakan metode grey-wolf optimizer.

\section{TINJAUAN PUSTAKA}

\subsection{Rumusan Matematis Optimal Reactive Power Dispatch}

Masalah penyaluran daya reaktif optimal untuk meminimisasi rugi-rugi daya aktif dapat dirumuskan sebagai berikut:

$$
\min f_{p}=\sum_{k \in N_{E}} P_{\text {loss }}=\sum_{k \in N_{E}} G_{k}\left(V_{i}^{2}+V_{j}^{2}-2 V_{i} V_{j} \cos \theta_{i j}\right)
$$

dengan memenuhi fungsi batasan-fungsi batasan, yakni:

1. Fungsi batasan persamaan (equality constraints) keseimbangan daya aktif dan daya reaktif yang dibangkitkan dan daya aktif dan daya reaktif yang digunakan, atau dapat dinyatakan dengan:

$$
\begin{aligned}
& P_{g_{i}}-P_{d_{i}}=V_{i} \sum_{j \in N_{i}} V_{j}\left(G_{i j} \cos \theta_{i j}+B_{i j} \sin \theta_{i j}\right) \\
& Q_{g_{i}}-Q_{d_{i}}=V_{i} \sum_{j \in N_{i}} V_{j}\left(G_{i j} \cos \theta_{i j}+B_{i j} \sin \theta_{i j}\right)
\end{aligned}
$$

dimana $P_{g_{i}}$ dan $Q_{g_{i}}$ adalah daya aktif dan daya reaktif yang dibangkitkan pada bus $i, P_{d_{i}}$ dan $Q_{d_{i}}$ adalah daya aktif dan daya reaktif yang dibutuhkan pada bus $i, V_{i}$ dan $V_{j}$ adalah tegangan pada bus $i$ dan bus $j$, dan $G_{i j}, B_{i j}$ dan $\theta_{i j}$ masing-masing menyatakan konduktansi, suseptansi dan sudut antara bus $i$ dan bus $j$.

2. Fungsi batasan pertidaksaman (inequality constraint) yang dinyatakan dalam bentuk batasan operasi, yakni sebagai berikut:

$$
\begin{aligned}
P_{g i}^{\min } \leq P_{g i} \leq P_{g i}^{\max } & i=1, \ldots, N_{g} \\
V_{g i}^{\min } \leq V_{g i} \leq V_{g i}^{\max } & i=1, \ldots, N_{g} \\
T_{i}^{\min } \leq T_{i} \leq T_{i}^{\max } & i=1, \ldots, N_{t} \\
Q_{c i}^{\min } \leq Q_{c i} \leq Q_{c i}^{\max } & i=1, \ldots, N_{c}
\end{aligned}
$$

dimana,
- $P_{g i}, P_{g i}^{\max }, P_{g i}^{\min } \quad$ dan $\quad N_{g} \quad$ masing-masing menyatakan daya aktif, daya aktif maksimum, daya aktif minimum generator ke- $i$ dan jumlah generator.

- $V_{g i}, V_{g i}^{\max } \quad$ dan $\quad V_{g i}^{\min }$ masing-masing menyatakan tegangan, tegangan maksimum dan tegangan minimum dari generator ke- $i$.

- $T_{i}, T_{i}^{\max }, T_{i}^{\min }$ dan $N_{t} \quad$ masing-masing menyatakan seting tap, seting tap maksimum, seting tap minimum dari transformator ke- $i$ dan jumlah transformator.

- $Q_{c i}, Q_{c i}^{\max }, Q_{c i}^{\min } \quad$ dan $\quad N_{c} \quad$ masing-masing menyatakan kapasitas, kapasitas maksimum, kapasitas minimum kapasitor paralel ke- $i$ dan jumlah kapasitor paralel.

Nilai tap transformator dan kapasitas kapasitor merupakan variabel diskrit.

\subsection{Grey-Wolf Optimizer (GWO)}

Grey-Wolf Optimizer (GWO) adalah metode optimisasi meta-heuristik berbasis kumpulan cerdas (swarm intelligence) yang didasarkan pada perilaku sekumpulan anjing serigala abu-abu (grey-wolf) dalam memburu mangsa [6]. Hierarki sosial dari serigala abu-abu dimulai dari tingkatan teratas adalah serigala alpha, beta, delta dan omega. Hierarki sosial ini mempengaruhi keputusan (penyelesaian) akhir dalam perburuan mangsa.

Langkah dalam teknik GWO adalah hierarki sosial, pelacakan (tracking), pengepungan (encircling) dan penyerangan mangsa (attacking prey). GWO mempunyai sekumpulan perburuan (optimisasi) dengan tiga penyelesaian yakni alpha $(\alpha)$, beta $(\beta)$ dan delta $(\delta)$, dengan penyelesaian alpha adalah penyelesaian yang terbaik. Penyelesaian selebihnya adalah omega $(\omega)$.

Saat serigala abu-abu menyerang mangsa, mereka cenderung mengepungnya. Persamaan berikut menggambarkan perilaku pengepungan, yakni:

$$
\begin{aligned}
& \vec{D}=\left|\vec{C} \cdot \vec{X}_{p}(t)-\vec{X}(t)\right| \\
& \vec{X}(t+1)=\vec{X}_{p}(t)-\vec{A} \cdot \vec{D}
\end{aligned}
$$

dimana $t$ adalah iterasi saat ini, $\vec{X}$ adalah vektor posisi dari serigala abu-abu, $\vec{X}_{p}$ adalah vektor posisi dari mangsa dan $\vec{A}$ dan $\vec{C}$ adalah vektor koefisien yang dihitung dengan persamaan 
berikut:

$$
\begin{aligned}
& \vec{A}=2 \vec{a} \cdot \vec{r}_{1}-\vec{a} \\
& \vec{C}=2 \cdot \vec{r}_{2}
\end{aligned}
$$

dimana $r_{1}$ dan $r_{2}$ adalah vektor acak antara 0 dan 1 dan nilai $\vec{a}$ diset menurun dari 2 ke 0 selama iterasi.

Tiga penyelesaian yang terbaik disimpan dan kemudian penyelesaian omega diperbaharui posisinya sesuai dengan iterasi saat ini. Situasi ini dinyatakan dengan persamaan:

$$
\begin{aligned}
& \vec{D}_{\alpha}=\left|\vec{C}_{1} \cdot \vec{X}_{\alpha}-\vec{X}\right| \\
& \vec{D}_{\beta}=\left|\vec{C}_{2} \cdot \vec{X}_{\beta}-\vec{X}\right| \\
& \vec{D}_{\delta}=\left|\vec{C}_{3} \cdot \vec{X}_{\delta}-\vec{X}\right| \\
& \vec{X}_{1}=\vec{X}_{\alpha}-\vec{A}_{1} \cdot\left(\vec{X}_{\alpha}\right) \\
& \vec{X}_{2}=\vec{X}_{\beta}-\vec{A}_{2} \cdot\left(\vec{X}_{\beta}\right) \\
& \vec{X}_{3}=\vec{X}_{\delta}-\vec{A}_{3} \cdot\left(\vec{X}_{\delta}\right) \\
& \vec{X}_{(t+1)}=\frac{\vec{X}_{1}+\vec{X}_{2}+\vec{X}_{3}}{3}
\end{aligned}
$$

Metode GWO dalam penyelesaian optimal reactive power dispatch adalah dengan membentuk matriks populasi dengan baris menyatakan jumlah dimensi variabel kontrol dan kolom menyatakan jumlah serigala abu-abu sebagai search agent.

Nilai posisi (variabel kontrol) dari setiap search agent pada setiap iterasi dievaluasi untuk memperoleh nilai fungsi objektif (fitness), yakni rugi-rugi daya aktif dan tiga nilai fitness yang terbaik disimpan sebagai nilai skor, yakni skor alpha (alpha score), skor beta (beta score) dan skor delta (delta score). Posisi dari setiap search agent diperbaharui pada setiap iterasi selanjutnya. Hal ini dilakukan sampai nilai iterasi maksimum dicapai dengan menampilkan nilai fitness terbaik dan posisinya masingmasing.

\section{METODOLOGI PENELITIAN}

\subsection{Pemodelan Sistem Lampung}

Sistem kelistrikan Lampung dimodelkan dengan model bus, saluran dan beban. Model bus pada sistem Lampung merepresentasikan gardu induk dan bus utama sistem distribusi. Model

\begin{tabular}{|c|c|c|c|}
\hline \multirow{2}{*}{$\begin{array}{l}\text { No. } \\
\text { Bus }\end{array}$} & \multirow{2}{*}{ Nama Bus } & \multicolumn{2}{|c|}{ Beban Ekivalen } \\
\hline & & $\begin{array}{c}\text { Daya Aktif } \\
\text { (MW) }\end{array}$ & $\begin{array}{c}\text { Daya Reaktif } \\
\text { (MVAR) }\end{array}$ \\
\hline 1 & Bukit Asam & - & - \\
\hline 2 & Baturaja & $\wedge 64,8$ & 25,52 \\
\hline 3 & Blambangan Umpu & 0 & 0 \\
\hline 4 & Bukit Kemuning & 0 & 0 \\
\hline 5 & Besai & 0 & 0 \\
\hline 6 & Kotabumi & 0 & 0 \\
\hline 7 & Menggala & 0 & 0 \\
\hline 8 & Gumawang & 0 & 0 \\
\hline 9 & Tap Adijaya & 0 & 0 \\
\hline 10 & Tegineneng & 0 & 0 \\
\hline 11 & Pagelaran & 0 & 0 \\
\hline 12 & Batutegi & 0 & 0 \\
\hline 13 & Natar & 0 & 0 \\
\hline 14 & Sukarame & 0 & 0 \\
\hline 15 & Teluk Betung & 0 & 0 \\
\hline 16 & Seputih Banyak & 0 & 0 \\
\hline 17 & Metro & 0 & 0 \\
\hline 18 & Sutami & 0 & 0 \\
\hline 19 & Tarahan & 0 & 0 \\
\hline 20 & Sribawono & 0 & 0 \\
\hline 21 & New Tarahan & 0 & 0 \\
\hline 22 & Sebalang & 0 & 0 \\
\hline 23 & Kalianda & 0 & 0 \\
\hline 24 & Ulubelu & 2,64 & 0,63 \\
\hline 25 & Blambangan Umpu 1 & 6,2 & 3,05 \\
\hline 26 & Bukit Kemuning 1 & 23,3 & 11,36 \\
\hline 27 & Kotabumi 1 & 16,3 & 4,13 \\
\hline 28 & Kotabumi 2 & 19,7 & 6,73 \\
\hline 29 & Menggala 1 & 12,3 & 5,34 \\
\hline 30 & Menggala 2 & 22,9 & 10,81 \\
\hline 31 & Gumawang 1 & 21,1 & 7,88 \\
\hline 32 & Gumawang 2 & 14 & 10,34 \\
\hline 33 & Tap Adijaya 1 & 29,9 & 8,74 \\
\hline 34 & Tegineneng 1 & 7,4 & 3,82 \\
\hline 35 & Tegineneng 2 & 18,8 & 12,91 \\
\hline 36 & Tegineneng 3 & 12,5 & 8,46 \\
\hline 37 & Pagelaran 1 & 17,63 & 5,79 \\
\hline 38 & Pagelaran 2 & 19,18 & 6,31 \\
\hline 39 & Natar 1 & 20,04 & 6,59 \\
\hline 40 & Natar 2 & 24,94 & 8,2 \\
\hline 41 & Sukarame 1 & 24,2 & 11,28 \\
\hline 42 & Teluk Betung 1 & 33,3 & 27,57 \\
\hline 43 & Teluk Betung 2 & 34 & 16,82 \\
\hline 44 & Seputih Banyak 1 & 22,28 & 7,32 \\
\hline 45 & Metro 1 & 12,9 & 8,17 \\
\hline 46 & Metro 2 & 17,2 & 9,09 \\
\hline 47 & Sutami 1 & 16,1 & 10,82 \\
\hline 48 & Sutami 2 & 24,9 & 12,93 \\
\hline 49 & Tarahan 1 & 17,8 & 9,47 \\
\hline 50 & Tarahan 2 & 10,1 & 4,31 \\
\hline 51 & Sribawono 1 & 12,5 & 8,07 \\
\hline 52 & Sribawono 2 & 22,8 & 5,51 \\
\hline 53 & Kalianda 1 & 18,6 & 4,13 \\
\hline 54 & Kalianda 2 & 26 & 3,08 \\
\hline 55 & New Tarahan 1 & 28,2 & 14,05 \\
\hline
\end{tabular}
saluran menyatakan besaran resistansi, reaktansi dan suseptansi kabel antar saluran dan resistansi dan reaktansi transformator daya dalam per unit. Model beban dinyatakan dalam daya aktif dan daya reaktif (PQ). Pemodelan beban dilakukan dengan menggunakan data-data hasil pengukuran [7].

Tabel 2. Data Bus dan Beban Sistem Lampung

Sistem Lampung mempunyai 55 bus, dengan 24 bus $150 \mathrm{kV}$ dan 21 bus $20 \mathrm{kV}$, dan 58 
saluran, dengan 23 saluran transmisi antar gardu induk dan 25 saluran yang menghubungkan gardu induk dengan bus utama saluran distribusi. Data bus dan beban ditunjukkan pada Tabel 2 .

Tabel 3. Data Saluran Sistem Lampung

\begin{tabular}{|c|c|c|c|c|c|}
\hline \multirow[t]{2}{*}{ No } & \multirow{2}{*}{$\begin{array}{l}\text { Dari } \\
\text { Bus }\end{array}$} & \multirow{2}{*}{$\begin{array}{l}\text { Ke } \\
\text { Bus }\end{array}$} & \multicolumn{3}{|c|}{$\begin{array}{c}\text { Nilai Impedansi dan Suseptansi } \\
\text { Saluran (pu) }\end{array}$} \\
\hline & & & $\mathbf{R}$ & $\mathbf{X}$ & B \\
\hline 1 & 1 & 2 & 0,02144 & 0,06730 & 0,47091 \\
\hline 2 & 2 & 3 & 0,03673 & 0,11528 & 0,80659 \\
\hline 3 & 2 & 4 & 0,05498 & 0,17256 & 1,20739 \\
\hline 4 & 3 & 4 & 0,01825 & 0,05730 & 0,40090 \\
\hline 5 & 4 & 5 & 0,00433 & 0,01359 & 0,09506 \\
\hline 6 & 4 & 6 & 0,00969 & 0,03041 & 0,21279 \\
\hline 7 & 6 & 7 & 0,03297 & 0,10347 & 0,72399 \\
\hline 8 & 6 & 9 & 0,02580 & 0,08098 & 0,56660 \\
\hline 9 & 6 & 10 & 0,00791 & 0,02483 & 0,17376 \\
\hline 10 & 7 & 8 & 0,02995 & 0,08936 & 0,58418 \\
\hline 11 & 10 & 11 & 0,01104 & 0,03464 & 0,24238 \\
\hline 12 & 10 & 13 & 0,00519 & 0,01629 & 0,11395 \\
\hline 13 & 10 & 17 & 0,01205 & 0,03594 & 0,23496 \\
\hline 14 & 10 & 20 & 0,01864 & 0,08065 & 1,16860 \\
\hline 15 & 11 & 12 & 0,00814 & 0,03522 & 0,51028 \\
\hline 16 & 13 & 14 & 0,00694 & 0,02177 & 0,15235 \\
\hline 17 & 13 & 15 & 0,00476 & 0,01494 & 0,10451 \\
\hline 18 & 13 & 18 & 0,01731 & 0,05435 & 0,38025 \\
\hline 19 & 14 & 18 & 0,01038 & 0,03257 & 0,22790 \\
\hline 20 & 16 & 20 & 0,02304 & 0,06874 & 0,44937 \\
\hline 21 & 17 & 20 & 0,03061 & 0,09135 & 0,59715 \\
\hline 22 & 18 & 19 & 0,00456 & 0,01432 & 0,10016 \\
\hline 23 & 18 & 21 & 0,00150 & 0,01025 & 0,15728 \\
\hline 24 & 20 & 21 & 0,00449 & 0,03007 & 0,47201 \\
\hline 25 & 21 & 22 & 0,00097 & 0,00655 & 0,10201 \\
\hline 26 & 22 & 23 & 0,00326 & 0,02236 & 0,34311 \\
\hline 27 & 11 & 24 & 0,01640 & 0,07090 & 0,05200 \\
\hline 28 & 3 & 25 & 0,00016 & 0,00220 & 0 \\
\hline 29 & 4 & 26 & 0,00016 & 0,00218 & 0 \\
\hline 30 & 6 & 27 & 0,00049 & 0,00977 & 0 \\
\hline 31 & 6 & 28 & 0,00008 & 0,00055 & 0 \\
\hline 32 & 7 & 29 & 0,00057 & 0,01150 & 0 \\
\hline 33 & 7 & 30 & 0,00016 & 0,00215 & 0 \\
\hline 34 & 8 & 31 & 0,00016 & 0,00219 & 0 \\
\hline 35 & 8 & 32 & 0,00016 & 0,00213 & 0 \\
\hline 36 & 9 & 33 & 0,00017 & 0,00227 & 0 \\
\hline 37 & 10 & 34 & 0,00049 & 0,00977 & 0 \\
\hline 38 & 10 & 35 & 0,00017 & 0,00226 & 0 \\
\hline 39 & 10 & 3 & 0,00047 & 0,00937 & 0 \\
\hline 40 & 11 & 37 & 0,00013 & 0,00088 & 0 \\
\hline 41 & 11 & 38 & 0,00016 & 0,00209 & 0 \\
\hline 42 & 13 & 39 & 0,00016 & 0,00216 & 0 \\
\hline 43 & 13 & 40 & 0,00016 & 0,00214 & 0 \\
\hline 44 & 14 & 41 & 0,00017 & 0,00225 & 0 \\
\hline 45 & 15 & 42 & 0,00016 & 0,00217 & 0 \\
\hline 46 & 15 & 43 & 0,00017 & 0,00222 & 0 \\
\hline 47 & 16 & 44 & 0,00017 & 0,00220 & 0 \\
\hline 48 & 17 & 45 & 0,00016 & 0,00215 & 0 \\
\hline 49 & 17 & 46 & 0,00013 & 0,00088 & 0 \\
\hline 50 & 18 & 47 & 0,00016 & 0,00217 & 0 \\
\hline 51 & 18 & 48 & 0,00017 & 0,00220 & 0 \\
\hline 52 & 19 & 49 & 0,00016 & 0,00216 & 0 \\
\hline 53 & 19 & 50 & 0,00016 & 0,00216 & 0 \\
\hline 54 & 20 & 51 & 0,00049 & 0,00977 & 0 \\
\hline 55 & 20 & 52 & 0,00016 & 0,00217 & 0 \\
\hline 56 & 23 & 53 & 0,00008 & 0,00054 & 0 \\
\hline 57 & 23 & 54 & 0,00016 & 0,00216 & 0 \\
\hline 58 & 21 & 55 & 0,00017 & 0,00228 & 0 \\
\hline
\end{tabular}

Data saluran (dalam per unit) dengan basis daya 100MVA, basis tegangan $150 \mathrm{kV}$ dan basis impedansi $225 \mathrm{ohm}$ ditunjukkan pada Tabel 3.

\subsection{Simulasi Optimal Reactive Power Dispatch dari Sistem Lampung dengan GWO.} lain:

Simulasi dilakukan dengan skenario, antara

1. Mengatur tegangan pada seluruh bus yang terhubung dengan pembangkit, yakni bus 1 , bus 5 , bus 10 , bus 12 , bus 15 , bus 19 , bus 21 , bus 22 dan bus 24 . Nilai tegangan yang diatur adalah antara 0,95 pu sampai 1,05 pu.

2. Mengatur kapasitas kapasitor yang terpasang pada bus, yakni pada bus 13, bus 18 dan bus 23. Nilai kapasitas kapasitor yang diatur berkisar 0 sampai 25 MVAR.

3. Mengatur posisi tap pada sisi sekunder transformator pada saluran-saluran yang menghubungkan bus 8 dan bus 31, bus 8 dan bus 32 serta bus 16 dan bus 44 . Nilai tap yang diatur antara 0,95 sampai 1,025 per unit.

Prosedur simulasi optimal reactive power dispatch sistem Lampung menggunakan teknik grey-wolf optimizer diringkaskan sebagai berikut:

1. Masukkan data-data bus, saluran dan beban sistem Lampung.

2. Tentukan parameter-parameter awal simulasi yakni jumlah iterasi, jumlah search agent, dimensi pencarian (jumlah kumpulan) dan batas atas dan batas bawah dari variabelvariabel yang dikontrol.

3. Inisialisasi posisi alpha, beta dan delta.

4. Evaluasi fungsi objektif untuk setiap search agent dan hitung rugi-rugi dengan perhitungan aliran daya.

5. Simpan hasil terbaik (fitness) sebagai skor alpha (alpha score) dan posisi alpha, hasil terbaik kedua sebagai skor beta (beta score) dan posisi beta dan hasil terbaik ketiga sebagai skor delta (delta score) dan posisi delta.

6. Perbaharui posisi alpha, beta dan delta.

7. Jika variabel di luar batas, masukkan ke batas variabel. Jika tidak, iterasi bertambah.

8. Cetak hasil terbaik (alpha score) dan posisi alpha (variabel-variabel).

Simulasi dilakukan dengan menggunakan perangkat lunak MATLAB [8], dengan program 
perhitungan aliran daya menggunakan perangkat lunak Matpower 5.1 [9]. Bagan alir pemrograman ditunjukkan pada Gambar 2 .

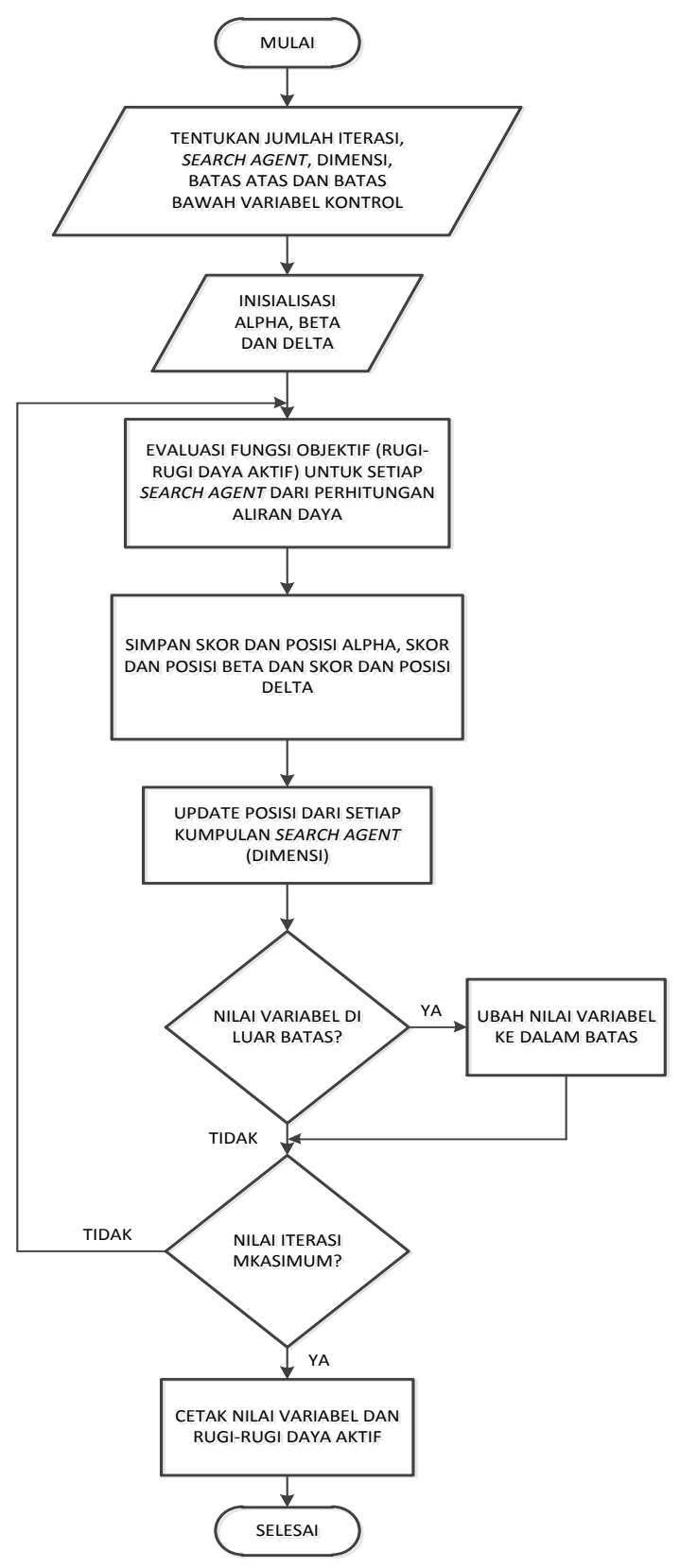

Gambar 2. Diagram Bagan Alir Pemrograman

\section{HASIL DAN PEMBAHASAN}

Diagram satu garis sistem Lampung ditunjukkan pada Gambar 4. Hasil perhitungan aliran daya menggunakan bahasa pemrograman Matpower 5.1 menunjukkan rugi-rugi sebelum optimisasi adalah sebesar 18,97 MW dan 66,93 MVAR.

Simulasi dilakukan dengan parameter- parameter GWO antara lain jumlah search agents 50 dan jumlah iterasi 100. Simulasi dilakukan sebanyak 50 kali dan hasil simulasi dengan rugi-rugi daya aktif yang paling minimum adalah pada simulasi ke-49, dengan total rugi-rugi daya aktif sebesar 18,2377 MW. Kurva konvergensi pada simulasi ke-49 ditunjukkan pada Gambar 3.

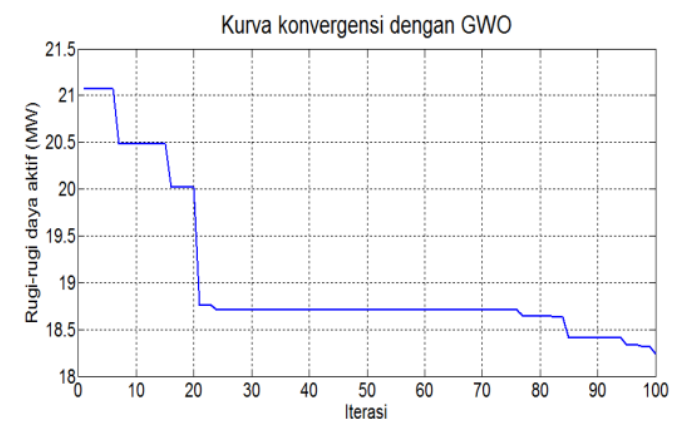

Gambar 3. Kurva Konvergensi Dengan GWO

Perbandingan hasil simulasi variabelvariabel yang dikontrol sebelum optimisasi dan sesudah optimisasi menggunakan metode GWO ditunjukkan pada Tabel 3 di bawah ini

Tabel 3. Hasil Simulasi Variabel Kontrol Sebelum dan Sesudah Optimisasi Menggunakan GWO

\begin{tabular}{|c|c|c|}
\hline Variabel & $\begin{array}{c}\text { Sebelum } \\
\text { Optimisasi }\end{array}$ & $\begin{array}{c}\text { Sesudah } \\
\text { Optimisasi }\end{array}$ \\
\hline$V_{1}(\mathrm{pu})$ & 1,0 & 0,9684 \\
\hline$V_{5}(\mathrm{pu})$ & 1,0 & 0,9510 \\
\hline$V_{10}(\mathrm{pu})$ & 1,0 & 0,9536 \\
\hline$V_{12}(\mathrm{pu})$ & 1,0 & 0,9683 \\
\hline$V_{15}(\mathrm{pu})$ & 1,0 & 0,95 \\
\hline$V_{19}(\mathrm{pu})$ & 1,0 & 0,9569 \\
\hline$V_{21}(\mathrm{pu})$ & 1,0 & 0,9571 \\
\hline$V_{22}(\mathrm{pu})$ & 1,0 & 0,9582 \\
\hline$V_{24}(\mathrm{pu})$ & 1,0 & 0,9894 \\
\hline$T_{34}(\mathrm{pu})$ & 1 & 1,0008 \\
\hline$T_{35}(\mathrm{pu})$ & 1 & 1,0152 \\
\hline$T_{47}(\mathrm{pu})$ & 1 & 0,9655 \\
\hline$Q_{\mathrm{c} 13}(\mathrm{MVAR})$ & 25 & 8,7762 \\
\hline$Q_{\mathrm{c} 18}(\mathrm{MVAR})$ & 25 & 4,4951 \\
\hline$Q_{\mathrm{c} 23}(\mathrm{MVAR})$ & 25 & 10,1999 \\
\hline Total Rugi-rugi Daya & 18,97 & 18,2377 \\
\hline Aktif $(\mathrm{MW})$ & & \\
\hline
\end{tabular}

Tabel 3 menunjukkan bahwa tegangan operasi pada bus yang terhubung dengan generator sesudah optimisasi lebih kecil dari tegangan sebelum dilakukan optimisasi, hal ini berhubungan dengan pengurangan daya reaktif yang disuplai seluruh generator dari 827,36 MVAR menjadi 676,199 MVAR. Daya reaktif total yang digunakan oleh beban adalah 299,23 MVAR. 


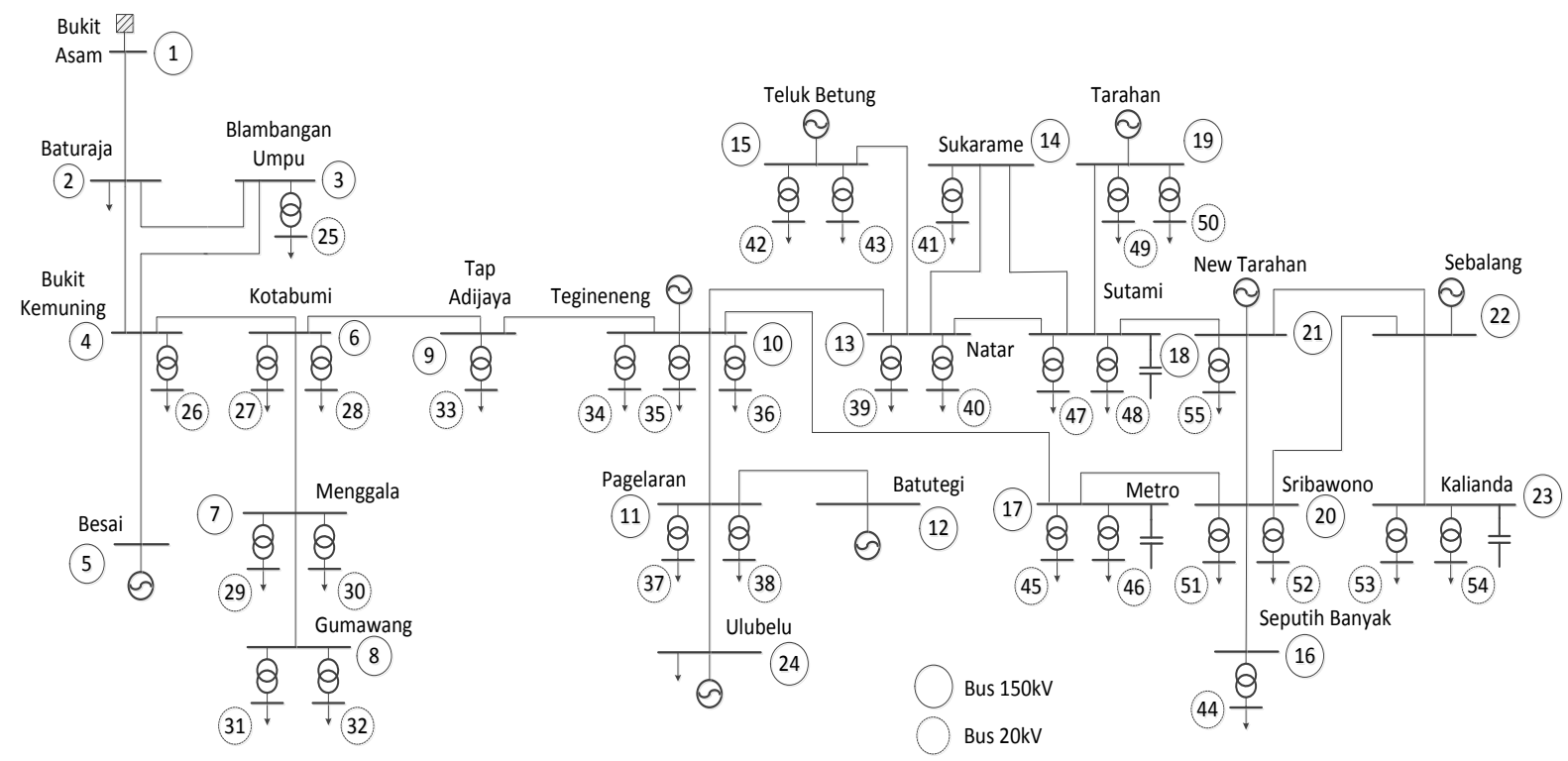

Gambar 4. Diagram Satu Garis Sistem Lampung

Pengurangan daya reaktif yang disuplai oleh kapasitor paralel berkurang dari 75 MVAR menjadi 23,4712 MVAR. Pengurangan daya reaktif dari generator dengan penurunan tegangan keluarannya dan penurunan daya reaktif dari kapasitor paralel ini menurunkan besar arus yang mengalir pada saluran transmisi, sehingga mengurangi rugi-rugi daya aktif total sistem Lampung.

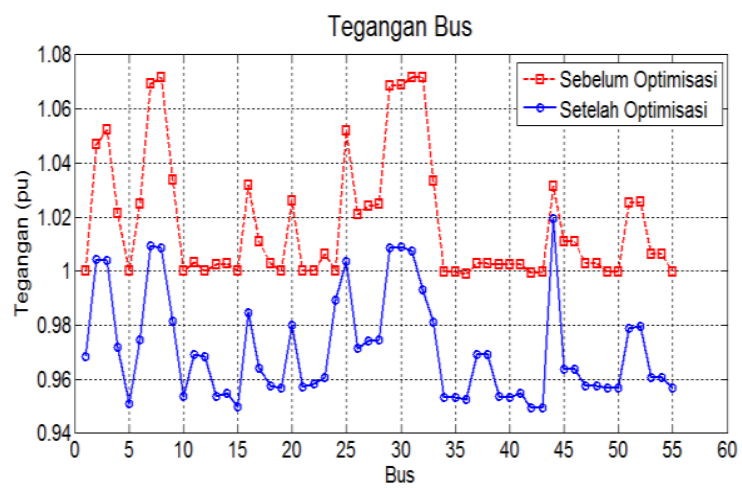

Gambar 5. Tegangan Setiap Bus Sebelum dan Setelah Optimisasi dengan GWO

Tegangan pada setiap bus sebelum dan setelah optimisasi dengan GWO ditunjukkan pada Gambar 5. Tegangan setiap bus setelah optimisasi lebih rendah dari tegangan sebelum optimisasi, sehingga mengurangi rugi-rugi daya aktif total sesuai persamaan (1)-(3). Selain itu, perbedaan tegangan antara dua bus yang berdekatan semakin kecil dan hal ini juga menunjukkan bahwa arus yang mengalir pada saluran yang menghubungkan kedua bus menjadi lebih kecil sehingga mengurangi rugirugi daya aktif dan rugi-rugi daya reaktif. Tegangan pada setiap bus hasil optimisasi masih berada dalam batas aman operasi, yakni lebih besar dari nilai $0,95 \mathrm{pu}$.

Rugi-rugi daya aktif dari 50 simulasi ditunjukkan pada Gambar 6.

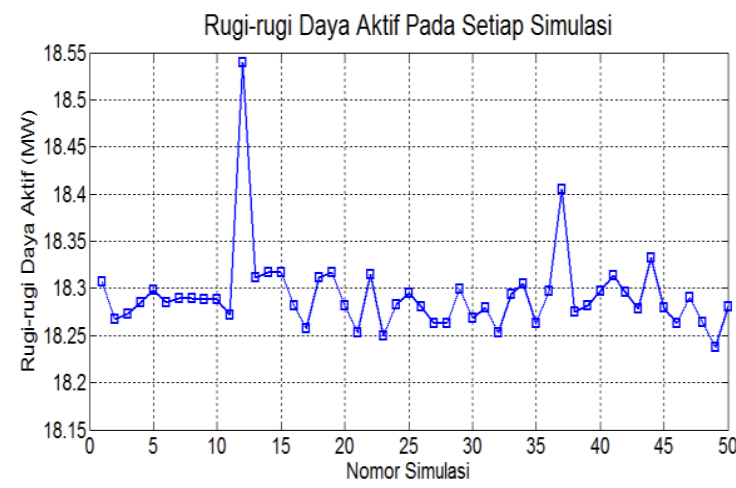

Gambar 6. Rugi-rugi Daya Aktif Pada Setiap Simulasi

Hasil simulasi sebanyak 50 kali dengan 100 iterasi untuk setiap simulasi menunjukkan bahwa metode GWO mampu menemukan rugirugi daya aktif total yang lebih kecil dari rugirugi daya aktif total sebelum dilakukan optimisasi dengan masing-masing nilai variabel kontrol. 


\section{KESIMPULAN}

1. Metode Grey-Wolf Optimizer (GWO) dapat menyelesaikan masalah optimal reactive power dispatch untuk meminimisasi rugi-rugi daya aktif sistem Lampung dengan mengurangi rugi-rugi daya aktif total dari 18,97 MW menjadi 18,2377 MW.

2. Metode GWO membutuhkan banyak simulasi untuk memperoleh rugi-rugi daya aktif yang paling minimum.

\section{DAFTAR PUSTAKA}

[1] Kirschen, D.S., and van Meteeren, H.P., MW/Voltage Control in a Linear Programming Based Optimal Power Flow, IEEE Trans. on Power Systems, vol.3, no.2, pp.481-489 (1988).

[2] Soler, E.M., Asada, E.N., and da Costa, G.R.M., Penalty-Based Nonlinear Solver for Optimal Reactive Power Dispatch With Discrete Control, IEEE Trans. on Power Systems, vol.28, no.3, pp.21742182 (2013).

[3] Zhao, B., Guo, C.X., and Cao, Y.J., $A$ Multiagent-Based Particle Swarm Optimization Approach for Optimal Reactive Power Dispatch, IEEE Trans. on Power Systems, vol.20, no.2, 1070-1078 (2005).

[4] Ayan, K., and Kilic, U., Artificial Bee Colony Algorithm Solution for Optimal Reactive Power Flow, Applied Soft Computing, vol.12, no.5, pp.1477-1482 (2012).
[5] Varadarajan, M., and Swarup, K.S., Differential Evolution Approach for Optimal Reactive Power Dispatch, Applied Soft Computing, vol.8, no.4, pp.1549-1561 (2008).

[6] Mirjalili, S., Mirjalili, S.M., and Lewis, A., Grey-Wolf Optimizer, Advances in Engineering Software, vol.69, pp.46-61, (2014).

[7] PT. PLN (Persero) UPT Tanjung Karang, Data Pengukuran Gardu Induk dan Single Line Diagram Sistem Kelistrikan Lampung, (2012).

[8] MATLAB 7.12.0.635 (R2011a) User Guide, www.mathwork.com, (2011).

[9] Zimmerman, R.D., Murillo-Sanchez, C.E. and Thomas, R.J., Matpower: SteadyState Operations, Planning and Analysis Tools for Power Systems Research and Education, IEEE Trans. on Power Systems, vol.26, no.1, pp.12-19 (2011).

\section{Biodata Penulis}

Osea Zebua, menamatkan pendidikan S1 di Jurusan Teknik Elektro Universitas Sumatera Utara tahun 1995 dan pendidikan S2 di Jurusan Teknik Elektro Universitas Gadjah Mada tahun 2001.

I Made Ginarsa, menamatkan pendidikan S1 di Jurusan Teknik Elektro Universitas Udayana tahun 1997, pendidikan S2 di Jurusan Teknik Elektro Universitas Gadjah Mada tahun 2001 dan pendidikan S3 di Jurusan Teknik Elektro Institut Teknologi Sepuluh Nopember tahun 2012. 